Open Access

\title{
Genome sequence of the clover symbiont Rhizobium leguminosarum bv. trifolii strain CC275e
}

Clément Delestre ${ }^{1}$, Aurélie Laugraud ${ }^{2}$, Hayley Ridgway ${ }^{3}$, Clive Ronson ${ }^{4}$, Maureen O'Callaghan ${ }^{2}$, Brent Barrett ${ }^{5}$, Ross Ballard ${ }^{6}$, Andrew Griffiths ${ }^{5}$, Sandra Young ${ }^{2}$, Celine Blond ${ }^{3}$, Emily Gerard ${ }^{2}$ and Steve Wakelin ${ }^{2 *}$

\begin{abstract}
Rhizobium leguminosarum bv. trifolii strain CC275e is a highly effective, $\mathrm{N}_{2}$-fixing microsymbiont of white clover (Trifolium repens L.). The bacterium has been widely used in both Australia and New Zealand as a clover seed inoculant and, as such, has delivered the equivalent of millions of dollars of nitrogen into these pastoral systems. R. leguminosarum strain CC275e is a rod-shaped, motile, Gram-negative, non-spore forming bacterium. The genome was sequenced on an Illumina MiSeq instrument using a $2 \times 150$ bp paired end library and assembled into 29 scaffolds. The genome size is 7,077,367 nucleotides, with a GC content of $60.9 \%$. The final, high-quality draft genome contains 6693 protein coding genes, close to $85 \%$ of which were assigned to COG categories. This Whole Genome Shotgun project has been deposited at DDBJ/EMBL/GenBank under the accession JRXL00000000. The sequencing of this genome will enable identification of genetic traits associated with host compatibility and high $\mathrm{N}_{2}$ fixation characteristics in Rhizobium leguminosarum. The sequence will also be useful for development of strain-specific markers to assess factors associated with environmental fitness, competiveness for host nodule occupancy, and survival on legume seeds (New Zealand Ministry of Business, Innovation and Employment program, 'Improving forage legume-rhizobia performance' contract C10X1308 and DairyNZ Ltd.).
\end{abstract}

Keywords: Root-nodule bacteria, Microsymbiont, Nitrogen fixation, Rhizobia, Alphaproteobacteria

\section{Introduction}

White clover (Trifolium repens) is the most widely established and important legume in pastures in New Zealand [1] and globally [2]. In symbiosis with nodule-forming Rhizobium leguminosarum bacteria of the biovar trifolii (hereafter $R$. leguminosarum bv trifolii), clover plants fix atmospheric nitrogen into a plant-available, thus providing an economically and environmentally sustainable method of maintaining soil fertility and pasture production. Across New Zealand there are 11,400+ farms using pastures containing forage legumes (mostly white clover), covering 7.88 million hectares [3]. This constitutes about $29 \%$ of the total land area and excludes hill country/tussock grasslands. Estimates of nitrogen input from

\footnotetext{
* Correspondence: Steve.Wakelin@agresearch.co.nz

${ }^{2}$ AgResearch Ltd, Lincoln Campus, Private Bag 4749, Christchurch 8140, New Zealand

Full list of author information is available at the end of the article
}

legumes vary, however average at $185 \mathrm{~kg} \mathrm{~N} \mathrm{ha}^{-1} \mathrm{yr}^{-1}$ for pastures with a slope less than $12^{\circ}$ [4]. Based on recent average costs of urea fertilizer (2013-14 average), the value of $\mathrm{N}_{2}$ fixation into New Zealand pastures is 1.8 billion per year; this is highly conservative as it does not encompass the value of increased forage quality, $\mathrm{N}_{2}$ fixation in extensive hill country systems, and reduced environmental costs.

R. leguminosarum $b v$ trifolii strains vary extensively in their ability to form nodules with white clover [5], and also their effectiveness at fixing nitrogen during symbiosis [6]. As such, dedicated selection and screening programs have played a vital role in ensuring clover (and, of course, other legume species) are matched with an optimal rhizobia symbiont [7]. These are most commonly delivered into farming systems as rhizobia-inoculated seed [8].

The inoculation of white clover seed with rhizobia commenced in New Zealand in the early 20th century 


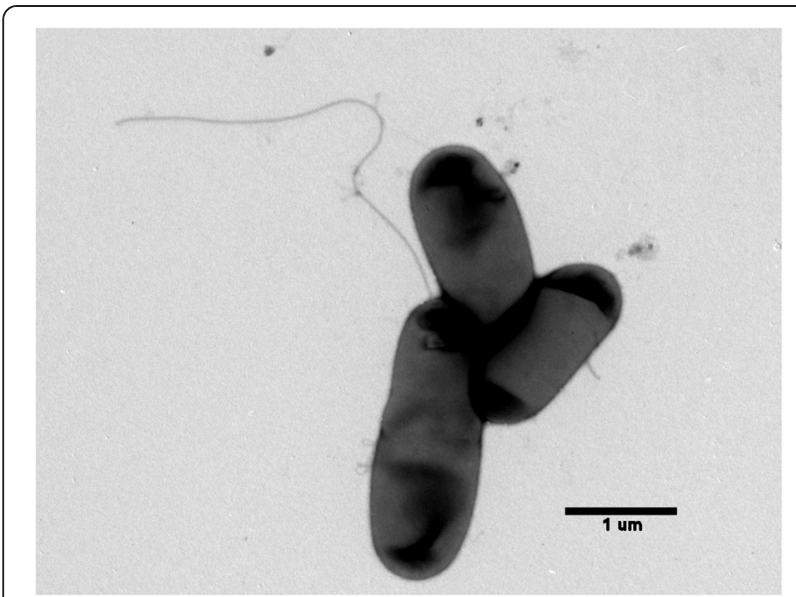

Fig. 1 TEM micrograph of three Rhizobium leguminosarum bv. trifolii CC275e cells. The length of the bar $=1 \mathrm{um}$

[8]. In addition to New Zealand produced inoculant strains, $R$. leguminosarum bv trifolii strain CC275e was sourced from Australia [9]. From 1974, the inoculant production in New Zealand industry was phased-out and the sole commercial strain for inoculation of white clover seed was strain CC275e, which was then replaced with $R$. leguminosarum $b v$ trifolii strain TA1 (also from Australia) around 2005. Thus, R. leguminosarum bv trifolii strain CC275e was in widespread use in New Zealand for approximately three decades, and is likely to have contributed billions of dollars of nitrogen into New Zealand's pastoral systems. On white clover, $R$. leguminosarum $b v$ trifolii strain $C$ C275e has been reported to fix more nitrogen than strain TA1 and has greater persistence in soils [9]. The decision by the inoculant industry to replace strain $\mathrm{CC} 275 \mathrm{e}$ with strain TA1 was based on ease of production.

A number of synonyms of strain $R$. leguminosarum $b v$ trifolii strain CC275e exist. In New Zealand, a culture of strain CC275e was received by the Plant Diseases Division of the Department of Scientific and Industrial Research in 1974 and a re-isolate of this culture is referred to as strain PDD2163. Furthermore, in New Zealand, strain CC275e has also been referred to as strain W16 [10], but when used commercially was most commonly known as strain NZP561 [11]. In Australia, where the bacterium originates, early work referred to it as strain W16 or Strain Hastings T71 [10]. However, strain CC275e was the designation used when the bacterium was deposited in the CSIRO (Canberra) culture collection [12], and this is the most commonly used synonym. In the American Type Culture Collection, the bacterium is referred to as ATCC 35181 . For this study, an original $R$. leguminosarum bv trifolii strain CC275e culture was obtained from the Australian Inoculant Research Group (Gosford, NSW, Australia).
These sequence data complements those of Trifoliumnodulating $R$. leguminosarum bv trifolii strain WSM1325 (GenBank ID 241202755), strain WSM2304 (GenBank ID 209547612), strain WSM1689 (GenBank ID 752843554), and strain TA1 (GenBank ID 653806106).

\section{Organism information}

\section{Classification and features}

Rhizobium leguminosarum bv. trifolii strain CC275e is a Gram-negative, motile, non-spore forming, nonencapsulated, rod shaped bacterium (Fig. 1). Colonies of R. leguminosarum bv trifolii strain CC275e form within 4 to 5 days when grown on yeast mannitol agar (YMA; [13]) at $25{ }^{\circ} \mathrm{C}$. Colonies are white-opaque, domed and glassy in appearance, with smooth margins.

Rhizobium leguminosarum and closely related species are generally regarded as non-fastidious, chemoorganotrophic bacteria [14]. Although the wider substrate requirements for strain $\mathrm{CC} 275 \mathrm{e}$ have not been formally described, the authors support this classification based on personal experience in the handling, cultivation and fermentation of R. leguminosarum bv trifolii strain CC275e.

The $R$. leguminosarum bv trifolii strain CC275e genome contains three (100\% identical) copies of the $16 \mathrm{~S}$ rRNA gene. Alignment of these nucleotide sequences against other species supports close 16S rRNA phylogeny with $R$. leguminosarum originating from other legume hosts (Fig. 2). The 16S rRNA gene sequence has highest similarity to other accessions of $R$. leguminosarum biovars trifolii (99.8 \%) and phaseoli (99.6 \%) (Fig. 2) - the GenBank accession numbers for these are provided in Additional file 1: Table S1. The species is placed within the order Rhizobiales of the class Alphaproteobacteria [15]. Minimum information about the Genome Sequence (MIGS) is provided in Table 1.

\section{Symbiotaxonomy}

R. leguminosarum bv trifolii strain CC275e is nodule forming $\left(\mathrm{Nod}^{+}\right)$and $\mathrm{N}_{2}$ fixing $\left(\mathrm{Fix}^{+}\right)$on a range of annual and perennial clover host species. The original isolation of $R$. leguminosarum bv trifolii strain CC275e was from Trifolium repens L. collected from Montague, North Western Tasmania [12], and has been used commercially due to its efficacy at forming symbioses and fixation of nitrogen on white clover hosts [9]. The strain is also moderately effective (sensu Brockwell et al. [12]) on T. fragiferum $\mathrm{L}$. (strawberry clover; perennial), and $T$. michelianum Savi, (balansa clover; annual). On T. subterraneum L. (subterranean clover; annual), T. purpureum Lois. (purple clover; annual), and T. hirtum All. (rose clover; annual), strain $\mathrm{CC} 275 \mathrm{e}$ has been described as effective [12]. 


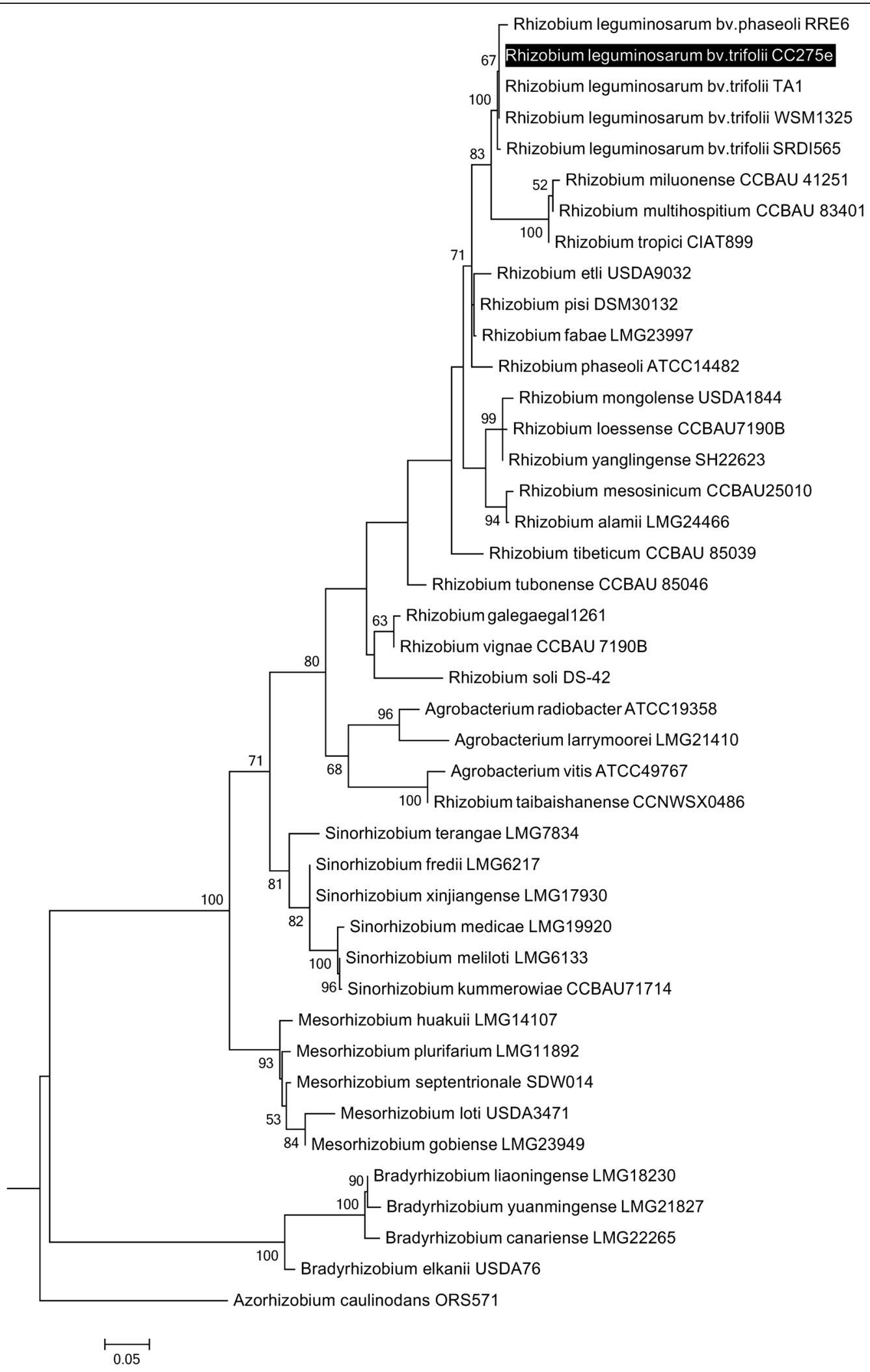

Fig. 2 (See legend on next page.) 
(See figure on previous page.)

Fig. 2 Phylogenetic tree showing relationship of R. leguminosarum bv trifolii CC275e with closely and distantly related taxa in the order Rhizobiales. The tree is based on 1498 bp length alignment of the 16S rRNA gene using MUSCLE with default parameters [31]. The tree was constructed using maximum likelihood method, with the General Time Reversible model (rate 4 classes; [32]). Nodes with bootstrap (1000 repetitions) support $>50 \%$ are shown [33]. Accession numbers relating to the nucleotide sequences for each of the strains are listed in Additional file 1: Table S1

\section{Genome sequencing information}

\section{Genome project history}

R. leguminosarum bv trifolii strain CC275e was selected for sequencing based on its long history of commercial use as an inoculant for various clover (Trifolium spp.) hosts in Australia and New Zealand. In symbiosis with clover, this strain of bacteria has provided biologicallyfixed nitrogen into soils for several decades, and thereby contributed to the fertility and productivity of pastoral agricultural systems in two countries. As part of a New Zealand MBIE-funded program, 'Improving forage legume-rhizobia performance' (C10X1308), the genomics of elite host nodulating $\left(\operatorname{nod}^{+}\right)$and $\mathrm{N}_{2}$ fixing (fix ${ }^{+}$) strains are being compared with closely related, ineffective strains. The aim is to identify markers to facilitate rhizobia selection programs, and to provide experimental tools for host colonization/competition experiments. Based on efforts in other $R$. leguminosarum bv trifolii

Table 1 Classification and general features of Rhizobium leguminosarum bv. trifolii strain CC275e according to the MIGS recommendations [34]

\begin{tabular}{|c|c|c|c|}
\hline MIGS ID & Property & Term & Evidence codes $^{\mathrm{a}}$ \\
\hline & Current classification & Domain Bacteria & TAS [35] \\
\hline & & Phylum Proteobacteria & TAS [36] \\
\hline & & Class Alphaproteobacteria & TAS [37] \\
\hline & & Order Rhizobiales & TAS [38] \\
\hline & & Family Rhizobiaceae & TAS [15] \\
\hline & & Genus Rhizobium & TAS [15] \\
\hline & & Species Rhizobium leguminosarum & TAS [14] \\
\hline & & Strain CC275e & TAS [12] \\
\hline & Gram Stain & Negative & TAS [15] \\
\hline & Cell Shape & Rod & TAS [15] \\
\hline & Motility & Motile & TAS [15] \\
\hline & Sporulation & Non spore-forming & TAS [15] \\
\hline & Temperature range & Mesophile & TAS [15] \\
\hline & Optimum temperature & $28^{\circ} \mathrm{C}$ & NAS \\
\hline & $\mathrm{pH}$ range; optimum & Unknown & NAS \\
\hline & Carbon source & Varied, chemoorganotrophic & TAS [15] \\
\hline MIGS-6 & Habitat & Soil, root nodule & TAS [12] \\
\hline MIGS-6.3 & Salinity & Non-halophile & NAS \\
\hline MIGS-22 & Oxygen requirement & Aerobic & TAS [15] \\
\hline MIGS-15 & Biotic relationship & Free living, legume symbiotic & TAS [15] \\
\hline MIGS-14 & Pathogenicity & Non-pathogen & $\operatorname{TAS}[15,39]$ \\
\hline MIGS-4 & Geographic location & Tasmania, Australia & TAS [12] \\
\hline MIGS-5 & Sample collection date & 1966 & TAS [12] \\
\hline MIGS-4.1 & Latitude & Not recorded & \\
\hline MIGS-4.2 & Longitude & Not recorded & \\
\hline MIGS-4.3 & Depth & Not recorded & \\
\hline MIGS-4.4 & Altitude & Not recorded & \\
\hline
\end{tabular}

a Evidence codes - IDA Inferred from Direct Assay, TAS Traceable Author Statement (i.e., a direct report exists in the literature), NAS Non-traceable Author Statement (i.e., not directly observed for the living, isolated sample, but based on a generally accepted property for the species, or anecdotal evidence). These evidence codes are from the Gene Ontology project [34] 
Table 2 Genome sequencing project information for Rhizobium leguminosarum bv. trifolii strain CC275e

\begin{tabular}{|c|c|c|}
\hline MIGS ID & Property & Term \\
\hline MIGS-31 & $\begin{array}{l}\text { Finishing } \\
\text { quality }\end{array}$ & High-quality draft \\
\hline MIGS-28 & Libraries Used & $\begin{array}{l}\text { Illumina TruSeq }{ }^{\mathrm{TM}} \text { DNA Sample Preparation } \\
\text { Kit V2, } 2 \times 150 \text { bp paired end library }\end{array}$ \\
\hline MIGS-29 & $\begin{array}{l}\text { Sequencing } \\
\text { platform }\end{array}$ & |llumina MiSeq ${ }^{\mathrm{TM}}$ \\
\hline MIGS-31.2 & Fold coverage & $\begin{array}{l}3.75 \text { million reads, } \approx 150 \times \text { genome } \\
\text { coverage }\end{array}$ \\
\hline MIGS-30 & Assemblers & A5, SSPACE, Velvet Optimiser \\
\hline \multirow[t]{6}{*}{ MIGS-32 } & $\begin{array}{l}\text { Gene calling } \\
\text { method }\end{array}$ & Glimmer 3 \\
\hline & Locus Tag & \\
\hline & Genbank ID & JRXL00000000 \\
\hline & $\begin{array}{l}\text { Genbank Date } \\
\text { of Release }\end{array}$ & 27st October, 2014 \\
\hline & GOLD ID & Gp0113226 \\
\hline & BIOPROJECT & 259682 \\
\hline \multirow[t]{2}{*}{ MIGS-13 } & $\begin{array}{l}\text { Source } \\
\text { Material } \\
\text { Identifier }\end{array}$ & ATCC 35181 \\
\hline & $\begin{array}{l}\text { Project } \\
\text { relevance }\end{array}$ & Symbiotic $\mathrm{N}_{2}$ fixation, agriculture \\
\hline
\end{tabular}

Table 3 Genome statistics for Rhizobium leguminosarum bv. trifolii strain CC275e

\begin{tabular}{|c|c|c|}
\hline Attribute & Value & $\%$ of total \\
\hline Genome size (bp) & $7,077,367$ & 100.00 \\
\hline DNA coding (bp) & $6,201,447$ & 87.62 \\
\hline DNA G + C (bp) & $4,306,744$ & 60.90 \\
\hline DNA scaffolds & 29 & \\
\hline Total genes & 6747 & 100.00 \\
\hline Protein coding genes & 6693 & 99.00 \\
\hline RNA genes & 54 & 0.80 \\
\hline Pseudo genes & $\begin{array}{l}\text { not } \\
\text { determined }\end{array}$ & not determined \\
\hline Genes in internal clusters & $\begin{array}{l}\text { not } \\
\text { determined }\end{array}$ & not determined \\
\hline Genes with function prediction & 5018 & 74.37 \\
\hline Genes assigned to COGs & 5722 & 84.80 \\
\hline Genes with Pfam domains & 5682 & 84.22 \\
\hline Genes with signal peptides & 531 & 7.87 \\
\hline $\begin{array}{l}\text { Genes with transmembrane } \\
\text { helices }\end{array}$ & 1584 & 23.48 \\
\hline CRISPR repeats & 0 & \\
\hline
\end{tabular}

Table 4 Number of protein coding genes of Rhizobium leguminosarum bv. trifolii strain CC275e associated with the general COG functional categories

\begin{tabular}{|c|c|c|c|}
\hline Code & Value & $\%$ of total & COG category \\
\hline J & 189 & 2.69 & Translation \\
\hline A & 0 & 0.00 & RNA processing and modification \\
\hline K & 624 & 8.88 & Transcription \\
\hline L & 186 & 2.65 & Replication \\
\hline B & 2 & 0.03 & Chromatin structure and dynamics \\
\hline D & 38 & 0.54 & Cell cycle control \\
\hline Y & 0 & 0.00 & Nuclear structure \\
\hline V & 64 & 0.91 & Defense mechanisms \\
\hline $\mathrm{T}$ & 361 & 5.14 & Signal transduction mechanisms \\
\hline M & 297 & 4.23 & Cell wall/membrane/ biogenesis \\
\hline N & 96 & 1.37 & Cell motility \\
\hline Z & 0 & 0.00 & Cytoskeleton \\
\hline W & 0 & 0.00 & Extracellular structures \\
\hline$U$ & 74 & 1.05 & Intracellular trafficking \\
\hline $\mathrm{O}$ & 185 & 2.63 & Posttranslational modification \\
\hline C & 295 & 4.20 & Energy production and conversion \\
\hline G & 646 & 9.19 & Carbohydrate transport and metabolism \\
\hline$E$ & 672 & 9.56 & Amino acid transport and metabolism \\
\hline $\mathrm{F}$ & 108 & 1.54 & Nucleotide transport and metabolism \\
\hline $\mathrm{H}$ & 151 & 2.15 & Coenzyme transport and metabolism \\
\hline I & 238 & 3.39 & Lipid transport and metabolism \\
\hline P & 234 & 3.33 & Inorganic ion transport and metabolism \\
\hline Q & 95 & 1.35 & Secondary metabolites biosynthesis \\
\hline $\mathrm{R}$ & 623 & 8.87 & General function prediction only \\
\hline S & 544 & 7.74 & Function unknown \\
\hline - & 1305 & 18.57 & Not in COGs \\
\hline
\end{tabular}

strains (see accessions listed in the introduction) a sequencing strategy was developed using a predicted genome size of approximately $7 \mathrm{Mb}$. The genome sequencing and assembly was completed in 2014; summary information on the project is given in Table 2. The final $R$. leguminosarum bv trifolii CC275e genome assembly is a high-quality draft on 29 scaffolds, and resulted from approximately $150 \times$ sequencing coverage.

\section{Growth conditions and genomic DNA preparation}

A loop of a single colony of $R$. leguminosarum bv trifolii CC275e was inoculated into YM broth [13] and grown to mid-log phase via incubation at $28{ }^{\circ} \mathrm{C}$ at $200 \mathrm{rpm}$ for $12 \mathrm{~h}$. DNA was extracted from the cell culture using a Gentra Puregene Cell kit (Qiagen). Spectrophotometry was used to quantify the DNA and ensure quality was 


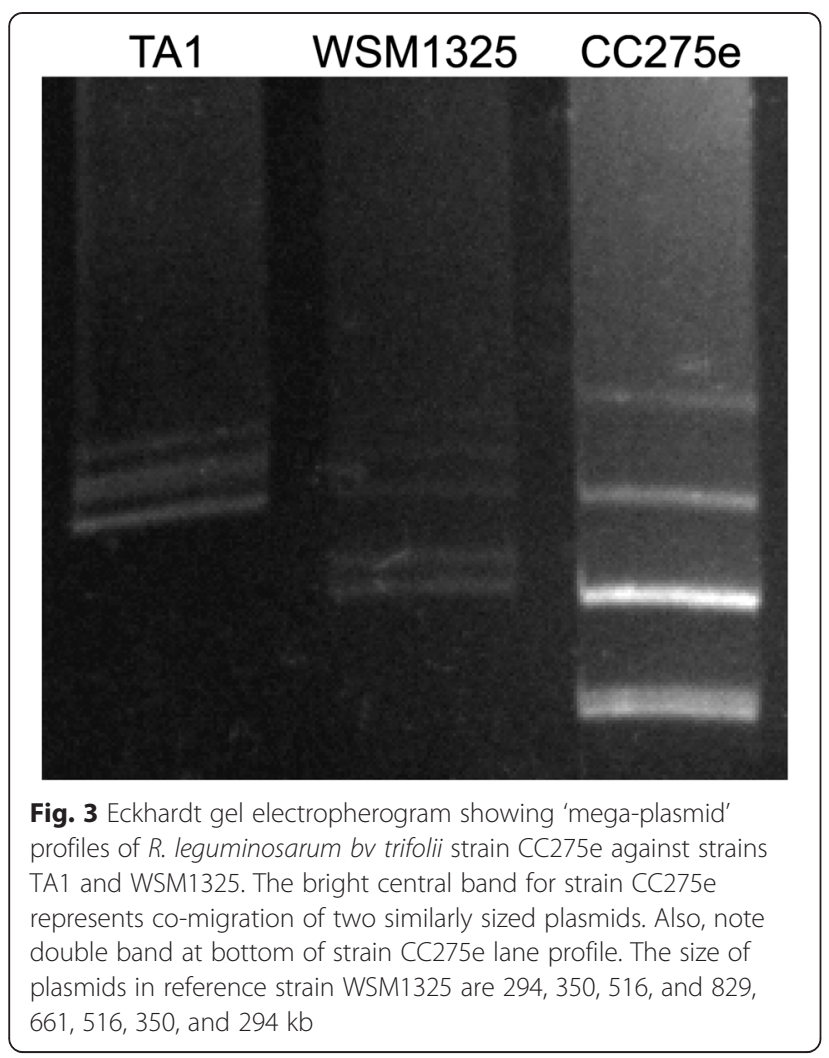

sufficient for sequencing analysis (Nanodrop Thermo Scientific).

\section{Genome sequencing and assembly}

Genome sequencing was conducted through NZGL (contract NZGL00940) at Massey University (MGS). Sequencing was performed on an Illumina $\mathrm{MiSeq}^{\mathrm{TM}}$ instrument (details in Table 2), using $2 \times 150$ bp pairedend (PE) library with an average insert size of $420 \mathrm{bp}$. The sequencing run generated 3,751,285 reads totaling $1088 \mathrm{Mb}$ of data.

Reads were assembled using the Java Assembling and Scaffolding Tool (JAST; [16]). Quality control of the sequence reads was conducted in Flexbar [17], and initial de novo assembly in A5 [18]; this resulted in 52 contigs. Bowtie2 [19] and Velvet [20] were further used to optimize the assembly, using the genome of the closely strain $R$. leguminosarum strain WSM1325 (Fig. 2) as a reference (NCBI accession 241202755). SSPACE [21] was used to assemble the 35 contigs into 29 scaffolds (Table 3). Summary details of the sequencing process are given in Table 2.

\section{Genome annotation}

Annotation was added by the NCBI Prokaryotic Genome Annotation Pipeline (http://www.ncbi.nlm.nih.gov/genome/annotation_prok/). Clusters of orthologous groups of proteins (COGs) were predicted using COGnitor [22], and the presence of signal peptides was detected using SignalP [23]. Pfam domains were predicted using HMMER [24] against the Pfam-A database [25]. Transmembrane predictions and CRISPR repeats were found in Genious [26] using the Transmembrane prediction (http://www.geneious.com/plugins/transmembrane-prediction-plugin) and CRT plugins [27] respectively.

\section{Genome properties}

The genome of $R$. leguminosarum $b v$ trifolii strain CC275e is estimated to be $7,077,367$ nucleotides in size (Table 3). The GC content is $60.9 \%$ which is similar to closely related strains such as $R$. leguminosarum bv trifolii strain TA1 (60.74\%; [28]). The final draft consists of 29 scaffolds, the largest of which is 1,609,666 bp and the smallest 1167 bp. In total, 6747 genes were identified, $99 \%$ of these were protein coding and the rest rRNA genes (Table 3 ). The majority of protein coding genes $(84.22 \%)$ have functionality predicted against COG categories; these are listed in Table 4. The remainder are listed as hypothetical.

Analysis of the genome by Eckhart gel electrophoresis [29] (Fig. 3) revealed the presence of six mega-plasmids. Mega-plasmids are typical of the 'ancillary genome' present in many $R$. leguminosarum strains [30] and commonly host many of the recognition factors associated with host compatibility, and nitrogen fixation. Based on the known mega-plasmid profile of $R$. leguminosarum $b v$ trifolii strain WSM1325 (Fig. 3), the mega-plasmids in $R$. leguminosarum bv trifolii strain CC275e are approximately $>1000,500,280,280,150$, and $140 \mathrm{~kb}$ in size. As yet it is unknown to which scaffolds these megaplasmids are associated.

\section{Conclusions}

Rhizobium leguminosarium bv. trifolii bacteria are an important resource for agricultural production $[1,2,4]$. In symbiosis with a suitable legume host (legume root nodules), atmospheric nitrogen fixed by these bacteria provides a source of plant nutrition that increases the farming system fertility in an economically and environmentally sustainable manner. Strains of $R$. leguminosarum bv trifolii vary in host-compatibility between legume species [5], and their nitrogen fixation efficacy when in symbiosis [6]. Understanding the genetic factors controlling these, and other phenotypes such as saprophytic survival, and desiccation tolerance, will enable increased utilization of $R$. leguminosarum bv trifolii for farming systems. The strain $R$. leguminosarum bv trifolii strain CC275e has been commercially used as an inoculant for white-clover for several decades [9]. The genome sequencing of this 'highly efficacious' bacterium, allows for the identification of genetic factors associated with 
desirable phenotypes (see previous). This will be achieved by comparison of the $R$. leguminosarum bv trifolii strain CC275e with closely related stains (e.g. based on 16S rRNA similarity) that differ in one or more phenotypes.

\section{Additional file}

Additional file 1: Table S1. List of strain names and associated NCBI GenBank accession numbers for bacterial isolates in Fig. 2. (XLSX 13 kb)

\author{
Abbreviations \\ CSIRO: Commonwealth scientific and industrial research organisation; Fix \\ +: Nitrogen fixation positive; NZGL: New Zealand genomics Ltd; Nod \\ +: Nodulation positive; MGS: Massey genome service; MBIE: Ministry of \\ business, innovation and employment; $R$. leguminosarum bv trifoli: Rhizobium \\ leguminosarum symbiovar trifolii; TEM: Transmission electron microscopy; \\ YM: Yeast mannitol.
}

\section{Competing interests}

The authors declare that they have no competing interests.

\section{Authors' contributions}

$S W, H R, C R, M O, B B, R B$, and $A G$ conceived of this study, participated in design, and helped draft the manuscript. CD and AL conducted genome assembly and associated bioinformatic analysis. SY, CB, and EG coordinated and conducted all microbiology, cell handling for TEM, DNA extraction and purification, and Eckhardt gel electrophoresis. All authors read and approved the final manuscript.

\section{Acknowledgements}

This work was funded through the New Zealand MBIE and DairyNZ funded programme "Improving forage legume-rhizobia performance" (C10X1308). Clément Delestre acknowledges the AgResearch bioinformatics team for internship funding. Sequencing was performed by MGS, and was coordinated by Lorraine Berry under NZGL contract NZGL00940 within the public-good funding stream. Sample QC, library QC, and library preparation was performed by Xiaoxiao Lin, sequencing by Richard Fong, and data QC by Mauro Truglio. Prof. Michael Hynes (University of Calgany) provided useful knowledge on $R$. leguminosarum mega-plasmids. TEM was conducted by Dr Duane Harland and James Vernon (AgResearch).

\section{Author details}

'University of Bordeaux, IT Science, 351 Cours de la Libération, 33400 Talence, France. ${ }^{2}$ AgResearch Ltd, Lincoln Campus, Private Bag 4749, Christchurch 8140, New Zealand. ${ }^{3}$ Faculty of Agriculture and Life Sciences, Lincoln University, PO Box 84, Christchurch, New Zealand. ${ }^{4}$ Department of Microbiology and Immunology, University of Otago, PO Box 56, Dunedin, New Zealand. ${ }^{5}$ AgResearch Ltd, Grasslands Research Centre, Private Bag 11008, Palmerston North, New Zealand. ${ }^{6}$ South Australian Research and Development Institute, Urrbrae, South Australia, Australia.

Received: 6 August 2015 Accepted: 2 November 2015

Published online: 08 December 2015

\section{References}

1. Caradus JR, Woodfield DR, Stewart AV. Overview and vision for white clover. Grassl Res Pract Ser. 1996;6:1-6.

2. Annicchiarico P, Barrett B, Brummer EC, Julier B, Marshall AH. Achievements and challenges in improving temperate perennial forage legumes. Crit Rev Plant Sci. 2015;34:327-80.

3. Statistics New Zealand. Agricultural areas in hectares, by usage and region, at 30 June 2012. 2012. Retrieved from: http://www.stats.govt.nz/browse_for_stats/ industry_sectors/agriculture-horticulture-forestry/2012-agricultural-censustables/land-use.aspx.

4. Ledgard SF, Sprosen MS, Penno JW, Rajendram GS. Nitrogen fixation by white clover in pastures grazed by dairy cows. Plant Soil. 2001;299:177-87.
5. Howieson JG, Yates RJ, O'Hara GW, Ryder M, Real D. The interactions of Rhizobium leguminosarum biovar trifolii in nodulation of annual and perennial Trifolium spp. from diverse centres of origin. Aust J Exp Agric. 2005;45:199-207.

6. Rhys GJ, Bonish PM. Effectiveness of Rhizobium trifolii populations associated with Trifolium species in Taranaki. New Zeal J Exp Agr. 1981;9:327-35.

7. Bullard GK, Roughley RJ, Pulsford DJ. The legume inoculant industry and inoculant quality control in Australia: 1953-2003. Aust J Exp Agric. 2005;45:127-40.

8. Cunningham GH. Certification of legume seed inoculants. N Z J Agric. 1957;94:578

9. Lowther WL, Kerr GA. White clover seed inoculation and coating in New Zealand. Proc N Z Grassl Assoc. 2011;73:93-102.

10. Brockwell J, Gibson AH. Root nodule bacteria for some cultivated species of Trifolium. J Aust Inst Agric Sci. 1968;34:224-7.

11. Mclntyre HJ, Davies H, Hore TA, Miller SH, Dufour JP, Ronson CW. Trehalose biosynthesis in Rhizobium leguminosarum bv. trifolii and its role in desiccation tolerance. Appl Environ Microbiol. 2007;73:3984-92.

12. Brockwell J, Mcllroy R, Hebb DM. The Australian collection of Rhizobium strains for temperate legumes. Catalogue 1998, CSIRO Plant Industry, Divisional Report No. 98/1, viii + 164 pp. Canberra: CSIRO Publishing; 1998.

13. Vincent JM. The cultivation, isolation and maintenance of rhizobia. In: Vincent JM, editor. A manual for the practical study of root-nodule bacteria. Oxford: Blackwell Scientific; 1970. p. 1-13.

14. Ramírez-Bahena MH, García-Fraile P, Peix A, Valverde A, Rivas R, Igual JM, et al. Revision of the taxonomic status of the species Rhizobium leguminosarum (Frank 1879) Frank $1889^{\mathrm{AL}}$, Rhizobium phaseoli Dangeard $1926^{\mathrm{AL}}$ and Rhizobium trifolii Dangeard $1926^{\mathrm{AL}}$. R. trifolii is a later synonym of $R$. leguminosarum. Reclassification of the strain R. leguminosarum DSM 30132 (=NCIMB 11478) as Rhizobium pisi sp. nov. Int J Syst Evol Microbiol. 2008;58:2484-90. doi:10.1099/ijs.0.65621-0.

15. Kuykendall LD, Young JM, Martínez-Romero E, Kerr A, Sawada H. Genus I. Rhizobium. In: Garrity GM, Brenner DJ, Krieg NR, Staley JT, editors. 'Bergey's manual of systematic bacteriology, vol. 2, Part C. 2nd ed. New York: Springer; 2005.

16. Delestre C. JAST: Java assembling and scaffolding tool. 2014. https://github. com/AgResearch/JAST Accessed July, 2014.

17. Dodt M, Roehr JT, Ahmed R, Dieterich C. Flexbar - flexible barcode and adapter processing for next-generation sequencing platforms. MDPI Biol. 2012; 1:895-905.

18. Tritt A, Eisen JA, Facciotti MT, Darling AE. An integrated pipeline for de novo assembly of microbial genomes. PLoS One. 2012;7:e42304. doi:10.1371/journal. pone.0042304.

19. Langmead B, Trapnell C, Pop M, Salzberg SL. Ultrafast and memory-efficient alignment of short DNA sequences to the human genome. Genome Biol. 2009;10:R25. doi:10.1186/gb-2009-10-3-r25.

20. Zerbino DR. Using the Velvet de novo Assembler for Short-Read Sequencing Technologies. Curr Protoc Bioinformatics. 2010;31:11.5.1-11.5.12. doi:10.1002/0471250953.bi1105s31.

21. Boetzer M, Henkel CV, Jansen HJ, Butler D, Pirovano W. Scaffolding preassembled contigs using SSPACE. Bioinformatics. 2011;27:578-9. doi:10. 1093/bioinformatics/btq683.

22. Tatusov RL, Koonin EV, Lipman DJ. A genomic perspective on protein families. Science. 1997;278:631-7.

23. Petersen TN, Brunak S, von Heijne G, Nielsen H. SignalP 4.0: discriminating signal peptides from transmembrane regions. Nat Methods. 2011;8:785-6.

24. Eddy SR. Accelerated Profile HMM Searches. PLoS Comput Biol. 2011;7: e1002195. doi:10.1371/journal.pcbi.1002195.

25. Finn RD, Bateman A, Clements J, Coggill P, Eberhardt RY, Eddy SR, et al. The Pfam protein families database: Nucleic Acids Research. Database Issue. 2014; 42:D222-30

26. Kearse M, Moir R, Wilson A, Stones-Havas S, Cheung M, Sturrock S, et al, Geneious Basic: an integrated and extendable desktop software platform for the organization and analysis of sequence data. Bioinformatics. 2012;28: $1647-9$

27. Bland C, Ramsey TL, Sabree F, Lowe M, Brown K, Kyrpides NC, et al. CRISPR Recognition Tool (CRT): a tool for automatic detection of clustered regularly interspaced palindromic repeats. BMC Bioinformatics. 2007;18:209.

28. Reeve W, Tian R, De Meyer S, Melino V, Terpolilli J, Ardley J, et al. Genome sequence of the clover-nodulating Rhizobium leguminosarum bv. trifolii strain TA1. Stand Genomic Sci. 2013;9:243-53. doi:10.4056/sigs.4488254.

29. Hynes MF, McGregor NF. Two plasmids other than the nodulation plasmid are necessary for formation of nitrogen-fixing nodules by Rhizobium leguminosarum. Mol Microbiol. 1990;4:567-74. 
30. Delcher AL, Bratke KA, Powers EC, Salzberg SL. Identifying bacterial genes and endosymbiont DNA with Glimmer. Bioinformatics. 2007;23:673-9.

31. Edgar RC. MUSCLE: a multiple sequence alignment method with reduced time and space complexity. BMC Bioinformatics. 2004;5:113. do:10.1186/ 1471-2105-5-113.

32. Tavaré S. Some Probabilistic and Statistical Problems in the Analysis of DNA Sequences. Lect Math Life Sci. 1986;17:57-86.

33. Felsenstein J. Confidence limits on phylogenies: an approach using the bootstrap. Evolution. 1985;39:783-91.

34. Field D, Garrity G, Gray T, Morrison N, Selengut J, Sterk P, et al. Towards a richer description of our complete collection of genomes and metagenomes "Minimum Information about a Genome Sequence " (MIGS) specification. Nat Biotechnol. 2008;26:541-7.

35. Woese CR, Kandler O, Wheelis ML. Towards a natural system of organisms: proposal for the domains Archaea, Bacteria, and Eucarya. Proc Natl Acad Sci U S A. 1990;87:4576-9.

36. Garrity GM, Bell JA, Lilburn T. Phylum XIV. Proteobacteria phyl. nov. In: Garrity GM, Brenner DJ, Krieg NR, Staley JT, editors. 'Bergey's manual of systematic bacteriology, vol. 2, Part B. 2nd ed. New York): Springer; 2005.

37. Garrity GM, Bell JA, Lilburn T. Class I. Alphaproteobacteria class. nov. In: Garrity GM, Brenner DJ, Krieg NR, Staley JT, editors. 'Bergey's manual of systematic bacteriology, vol. 2, Part C. 2nd ed. New York): Springer; 2005.

38. Kuykendall LD. Order VI. Rhizobiales ord. nov. In: Garrity GM, Brenner DJ, Krieg NR, Staley JT, editors. 'Bergey's manual of systematic bacteriology, vol. 2, Part C. 2nd ed. New York): Springer; 2005.

39. Biological Agents: Technical rules for biological agents. TRBA: 466

\section{Submit your next manuscript to BioMed Central and take full advantage of:}

- Convenient online submission

- Thorough peer review

- No space constraints or color figure charges

- Immediate publication on acceptance

- Inclusion in PubMed, CAS, Scopus and Google Scholar

- Research which is freely available for redistribution 